\title{
MICRONUTRIENT CONTENTS IN THE PROFILE OF A RECOVERED SOIL WITH SEWAGE SLUDGE AND NATIVE SPECIES OF ATLANTIC FOREST
}

\author{
Lívia Mara Lima Goulart1*, Marianne Fidalgo de Faria², Grasiela Spada², Thiago Tássio de Souza Silva², Iraê \\ Amaral Guerrini ${ }^{3}$
}

\begin{abstract}
${ }_{1}$ "Paulista State University "Júlio de Mesquita Filho" - University of Agronomic Sciences of Botucatu, Department of Soils and Environmental Resources, Graduate Program in Forestry Science, Botucatu, São Paulo, Brazil. - liviamlg@ hotmail.com ${ }^{2}$ Paulista State University "Júlio de Mesquita Filho" - University of Agronomic Sciences of Botucatu, Department of Soils and Environmental Resources, Graduate Program in Forestry Science, Botucatu, São Paulo, Brazil. - marianneffaria@hotmail.com ; gra_spada@hotmail.com;

3Paulista State University "Júlio de Mesquita Filho" - University of Agronomic Sciences of Botucatu, Department of Soils and Environmental Resources, Full Professor, Botucatu, São Paulo, Brazil. - iguerrini@fca.unesp.br
\end{abstract}

Received for publication: 08/05/2018 - Accepted for publication: 12/11/2018

\begin{abstract}
Resumo
Teores de micronutrientes no perfil de um solo recuperado com lodo de esgoto e espécies nativas da Mata Atlântica. A utilização do lodo de esgoto na agricultura e recuperação de áreas degradadas têm se mostrado como uma alternativa promissora para sua destinação final. Estudos sobre os níveis de micronutrientes após a aplicação do lodo são necessários para evitar a contaminação do solo a níveis tóxicos. Este trabalho teve por objetivo verificar os teores dos micronutrientes no perfil do solo e o seu $\mathrm{pH}$; até um metro de profundidade, nove anos após a aplicação de lodo de esgoto e plantio de espécies nativas da Mata Atlântica. $\mathrm{O}$ experimento foi implantado em Neossolo Quartzarênico degradado e conduzido em blocos casualizados com quatro repetições e oito tratamentos, constituídos por seis doses de lodo de esgoto $\left(0,2,5,5,10,15\right.$ e $20 \mathrm{Mg} \mathrm{ha}^{-1}$, com suplementação de potássio devido a sua baixa concentração no resíduo), além do tratamento controle, adubação mineral e apenas suplementação de potássio. Após nove anos, os teores de todos os micronutrientes avaliados apresentaram resposta significativa à aplicação dos tratamentos, sendo que a aplicação do lodo de esgoto proporcionou um aumento em seus teores. $\mathrm{O}$ pH do solo se manteve estável nos locais que receberam adubação mineral e suplementação com potássio. Apenas manganês e zinco apresentaram mobilidade no perfil do solo. A aplicação de lodo de esgoto em solo degradado aumenta os teores de micronutrientes e diminui sua movimentação no perfil do solo, sendo que a aplicação da dose máxima do resíduo não proporciona níveis tóxicos destes elementos no solo em longo prazo.
\end{abstract}

Palavras-chave: resíduo urbano, recuperação de áreas degradadas, lixiviação de nutrientes no solo

\begin{abstract}
The use of sewage sludge in agriculture and recovery of degraded areas has been shown as a promising alternative for its final destination. Studies on micronutrient levels after sludge application are necessary to avoid soil contamination at toxic levels. The objective of this work was to verify the micronutrient contents in the soil profile and $\mathrm{pH}$, up to one-meter-deep, nine years after the application of sewage sludge and planting of native species of the Atlantic Forest. The experiment was implemented in a degraded Quartzeneic Neosol and conducted in randomized blocks with four replicates and eight treatments, consisting of six doses of sewage sludge $\left(0,2.5,5,10,15\right.$ and $20 \mathrm{Mg} \mathrm{ha}^{-1}$, with supplementation of potassium due to low concentration in the residue), besides the control treatment, mineral fertilization and only potassium supplementation. After nine years, the contents of all micronutrients evaluated presented a significant response to the application of the treatments, and the application of sewage sludge provided an increase in their contents. Soil $\mathrm{pH}$ remained stable at sites receiving mineral fertilization and potassium supplementation. Only manganese and zinc showed mobility in the soil profile. The application of sewage sludge in degraded soil increases the micronutrient content and decreases its movement in the soil profile, and the application of the maximum dose of the residue does not provide toxic levels of these elements in the soil in the long term.

keywords: urban waste, recovery of degraded areas, leaching of nutrients in the soil.
\end{abstract}

\section{INTRODUCTION}

The recycling of sewage sludge in agriculture and to recover degraded areas has shown to be a promising alternative, since these destinations can transform waste into an agricultural input, hence the sludge contains some essential elements to plants, such as nitrogen, phosphorus, calcium and magnesium (SILVA et al., 2010), and micronutrients (CHIBA et al., 2008). Also, sludge has the ability to improve soil physical attributes, increasing water retention capacity, porosity and stability of the aggregates, mainly due to the increase of organic matter in the soil (RICCI et al., 2010). By improving the physical and chemical characteristics of the soil, sewage sludge contributes to its recovery as well. 
The presence of heavy metals is one of the main limitations to the use of sewage sludge in agriculture and forest areas. In general, the concentrations of metals found in the sludge are much higher than those found naturally in soils, thus the need to evaluate the risks associated with the increase of these elements in the environment due to the application of this residue (MESSIAS et al., 2007).

According to Andreoli and Pegorini (2000), the agricultural use of sewage sludge has been exhaustively researched all over the world, with no harmful effect on the environment, such as pollution with heavy metals, when used in any way different regulations. In the long run, however, the increase in the concentration of metals in the soil, resulting from the application of sludge, becomes a justified concern, because if it is not properly controlled it can threaten the food chain (NASCIMENTO et al., 2004).

Although copper, iron, zinc, manganese, and boron are micronutrients for plants, depending on their levels, they may become toxic and cause environmental contamination (NASCIMENTO et al., 2001). Additionally, the excess of these elements in the superficial layers of the soil can cause damages to the development of plants and contamination of agricultural crops as well as the groundwater by their leaching. Studies on the mobility of heavy metals in soil have shown that copper and iron have low mobility, accumulating on the surface of contaminated soils, while zinc and manganese are more mobile in the soil profile, representing a greater risk of contamination of groundwater (SHEPPARD; THIBAULT, 1992).

In soils of tropical regions, there is little information on the mobility of heavy metals, especially longterm studies, which is aggravated by the tendency of great mobility of these metals due to the predominance of weathered soils under high temperature and rainfall regimes. In this way, the objective of this study was to verify the micronutrient contents in the soil profile and the $\mathrm{pH}$, up to one-meter-deep, nine years after the application of sewage sludge and planting of native species of the Atlantic Forest.

\section{MATERIAL AND METHODS}

\section{Characterization of the experimental area}

The experiment was carried out at Fazenda Entre-Rios, from Suzano Papel e Celulose S/A in Angatuba, São Paulo, Brazil. The area is at the geographical coordinates of $23^{\circ} 18^{\prime}$ south latitude and $48^{\circ} 30^{\prime}$ west longitude of Greenwich, at $636 \mathrm{~m}$ altitude. The climate of the region is the Cwa type, a humid climate, warm, with dry winter. The lowest rainfall month is July $(20-30 \mathrm{~mm})$ and the wettest month, January $(200-225 \mathrm{~mm})$. The average annual temperature is $23^{\circ} \mathrm{C}$, with a minimum of $10^{\circ} \mathrm{C}$ in July and a maximum of $35^{\circ} \mathrm{C}$ in January.

The relief is flat and the original soil is Quartzeneic Neosol (EMBRAPA, 2013). The area was degraded by the loss of the superficial layer and with high level of compaction, since it was used as a wooden storage yard by the company for eleven years. Before the implementation of the experiment, soil samples were collected for chemical and physical analysis (Table 1).

Table 1. Chemical analysis and textural class of the soil in the $0-20 \mathrm{~cm}$ layer before the implantation of the experiment.

Tabela 1. Análise química e classe textural do solo na camada de 0-20 cm, antes da implantação do experimento.

\begin{tabular}{|c|c|c|c|c|c|c|c|c|c|}
\hline \multicolumn{10}{|c|}{ Chemical analysis } \\
\hline $\mathrm{pH}\left(\mathrm{CaCl}_{2}\right)$ & $\begin{array}{l}\text { M.O. } \\
\text { g dm }^{-3}\end{array}$ & $\mathrm{~K}^{+}$ & $\mathrm{K}^{+}$ & $\begin{array}{l}\mathrm{Ca}^{2+} \\
--\mathrm{cr}\end{array}$ & $\begin{array}{c}\mathrm{Mg}^{2+} \\
\mathrm{ll}_{\mathrm{c}} \mathrm{dm}^{-3}\end{array}$ & SB & $\mathrm{H}+\mathrm{Al}$ & CTC & $\mathrm{V} \%$ \\
\hline 4.4 & 9 & 0.4 & 0.043 & 0.43 & 0.1 & 0.57 & 23.3 & 28.3 & 18.5 \\
\hline $\mathrm{P}_{\text {res }}$ & $\mathrm{B}$ & $\begin{array}{l}\mathrm{Cu} \\
\mathrm{dm}^{-3}\end{array}$ & $\mathrm{Fe}$ & $\mathrm{Mn}$ & $\mathrm{Zn}$ & \multicolumn{4}{|c|}{$\begin{array}{c}\text { Textural class } \\
\text { Sandy }\end{array}$} \\
\hline 4.3 & 12.6 & 4.6 & 27.6 & 0.6 & 0.1 & \multicolumn{4}{|c|}{$($ sand $=900 \%$, silt $=8 \%$ and clay $=92 \%)$} \\
\hline
\end{tabular}

Source: Laboratory of Fertility and Soil Physics of FCA / UNESP - campus of Botucatu, SP, Brazil.

\section{Description of the experiment}

The experiment was started in March 2005, when the soil was scraped to remove spontaneous vegetation and soil preparation by means of cross-subsoiling, using a double-subsoil subsoiler at $40-50 \mathrm{~cm}$ depth. The treatments and the planting of the native species of the Atlantic Forest were then applied.

The experiment was performed in a randomized complete block design with 8 treatments and 4 replicates. In each plot were planted 81 seedlings ( 9 rows with 9 plants each), arranged in spacing of 3 meters between rows and 2 meters between plants (Figure 1). The floor area was represented by the 49 central plants. The treatments applied were: sewage sludge (dry basis): $2.5 ; 5 ; 10 ; 15$ and $20 \mathrm{Mg} \mathrm{ha}^{-1}$ with potassium (K) supplementation because of the low content of this nutrient in the residue; mineral fertilization; dose of $\mathrm{K}$ used as supplementation for sewage sludge and a control treatment (without sludge or any mineral fertilizer), applied in the planting line. $\mathrm{K}$ supplementation was done as $\mathrm{KCl}\left(26 \mathrm{~kg} \mathrm{ha}^{-1} \mathrm{~K}_{2} \mathrm{O}\right)$ in all plots that received the residue, the same amount supplied by the mineral fertilizer and in the parcel that received only this nutrient. The treatment with mineral fertilization, based on the recommendation of Gonçalves et al. (1996), was: $260 \mathrm{~kg} \mathrm{ha}^{-1}$ of the formula NPK 6-30-10+0.3\% Boron $+1 \mathrm{~kg} \mathrm{ha}^{-1}$ of Zinc, applied at the time of planting. The chemical fertilizers used were: ammonium sulfate, 
simple superphosphate, potassium chloride, and boric acid. Based on the soil analysis and the recommendations of fertilization and liming for native species of the Atlantic Forest suggested by Gonçalves et al. (1996), 1.089 $\mathrm{t}$ $\mathrm{ha}^{-1}$ of dolomitic limestone (PRNT $=90.95 \%$ ) was applied on the planting lines only in the treatment that received mineral fertilization. The sewage sludge used came from the sewage treatment station of the city of Jundiaí, São Paulo State, Brazil, and its chemical characterization is presented in Table 2.

\begin{tabular}{|l|l|l|l|l|l|l|l|l|}
\hline $\begin{array}{l}\text { Pau- } \\
\text { viola }\end{array}$ & Pau-viola & Pau-viola & Pau-viola & Pau-viola & Pau-viola & Pau-viola & Pau-viola & $\begin{array}{l}\text { Pau- } \\
\text { viola }\end{array}$ \\
\hline $\begin{array}{l}\text { Pau- } \\
\text { viola }\end{array}$ & Capixingui & Canafístula & Aroeira P. & Cedro-rosa & Capixingui & Mutamba & Aroeira P. & $\begin{array}{l}\text { Pau- } \\
\text { viola }\end{array}$ \\
\hline $\begin{array}{l}\text { Pau- } \\
\text { viola }\end{array}$ & Cedro-rosa & Jequitibá & Mutamba & Jatobá & Angico & Copaíba & Cedro-rosa & $\begin{array}{l}\text { Pau- } \\
\text { viola }\end{array}$ \\
\hline $\begin{array}{l}\text { Pau- } \\
\text { viola }\end{array}$ & Aroeira P. & Angico & Capixingui & Canafístula & Aroeira P. & Canafístula & Capixingui & $\begin{array}{l}\text { Pau- } \\
\text { viola }\end{array}$ \\
\hline $\begin{array}{l}\text { Pau- } \\
\text { viola }\end{array}$ & Canafístula & Jatobá & Cedro-rosa & Copaíba & Mutamba & Jequitibá & Angico & $\begin{array}{l}\text { Pau- } \\
\text { viola }\end{array}$ \\
\hline $\begin{array}{l}\text { Pau- } \\
\text { viola }\end{array}$ & Capixingui & Mutamba & Aroeira P. & Angico & Capixingui & Cedro-rosa & Aroeira P. & $\begin{array}{l}\text { Pau- } \\
\text { viola }\end{array}$ \\
\hline $\begin{array}{l}\text { Pau- } \\
\text { viola }\end{array}$ & Canafístula & Copaíba & Cedro-rosa & Jequitibá & Canafístula & Jatobá & Mutamba & $\begin{array}{l}\text { Pau- } \\
\text { viola }\end{array}$ \\
\hline $\begin{array}{l}\text { Pau- } \\
\text { viola }\end{array}$ & Aroeira P. & Angico & Capixingui & Mutamba & Aroeira P. & Angico & Capixingui & $\begin{array}{l}\text { Pau- } \\
\text { viola }\end{array}$ \\
\hline $\begin{array}{l}\text { Pau- } \\
\text { viola }\end{array}$ & Pau-viola & Pau-viola & Pau-viola & Pau-viola & Pau-viola & Pau-viola & Pau-viola & $\begin{array}{l}\text { Pau- } \\
\text { viola }\end{array}$ \\
\hline
\end{tabular}

Figure 1. Distribution of plant species in each of the eight plots within a block. Featured area $=$ border.

Figura 1. Distribuição de espécies de plantas em cada uma das oito parcelas dentro de um bloco. Área em destaque = bordadura.

Table 2. Chemical characterization of the sewage sludge used in the experiment.

Tabela 2. Caracterização química do lodo de esgoto utilizado no experimento.

\begin{tabular}{|c|c|c|c|c|c|c|c|c|}
\hline \multicolumn{9}{|c|}{ Chemical analysis } \\
\hline $\mathrm{N}_{\text {total }}$ & $P$ & K & $\mathrm{Ca}$ & $\mathrm{Mg}$ & $S$ & M.O. & Humid. & $\mathrm{C} / \mathrm{N}$ \\
\hline 2.5 & 16.6 & 1.9 & 12.2 & 2.3 & 19.2 & 440 & $55 \%$ & 8 \\
\hline $\mathrm{Cu}$ & $\mathrm{Zn}$ & $\mathrm{Fe}$ & B & $\mathrm{Cd}$ & $\mathrm{Cr}$ & $\mathrm{Ni}$ & $\mathrm{Pb}$ & $\mathrm{pH}$ \\
\hline 850 & 573 & 8902 & 2 & $\begin{array}{c}\mathrm{mg} \mathrm{dm} \\
8.24\end{array}$ & 162.7 & 37.8 & 164.4 & 5 \\
\hline
\end{tabular}

Source: Agronomic Institute of Campinas.

Soil sampling and analysis

After nine years of applying the treatments, the soil samples were collected in the planting lines for later chemical analysis in the laboratory. The soil was sampled in layers 0-20, 20-40, 40-60, 60-80 and 80-100 cm depth and 1 composite sample was collected (formed by 18 subsamples) every $20 \mathrm{~cm}$ depth, until 1 meter in each plot, totaling 160 samples. In order to collect the soil samples, screw augers of 1.5 meters were used, and for the homogenization of the samples, plastic buckets for each depth and plot were used. After homogenization, the samples were conditioned in plastic bags, air dried and passed through a $2 \mathrm{~mm}$ sieve.

Moreover, soil samples for micronutrient analysis were sent to the Soil Chemistry and Soil Fertility Laboratory of the Department of Soil and Environmental Resources of the Faculty of Agronomic Sciences of UNESP / Botucatu, SP. Copper, iron, manganese, zinc, boron, as well as soil $\mathrm{pH}$, were then analyzed according to the methodologies described by Raij et al. (2001).

Statistical analysis of data

The results obtained were submitted to statistical analysis. The averages of the data were compared by the Tukey test at $5 \%$, when $\mathrm{F}$ presented significant value. The results of the sludge doses were submitted to regression analysis, with a better fit model, when significant.

\section{RESULTS}

The application of treatments in degraded soil provided a significant effect on $\mathrm{pH}$ in all the layers of soil sampled. The mean $\mathrm{pH}$ values in each of the soil layers were compared by the Tukey's test at $5 \%$ probability and are presented in Table 3. In the soil surface layer, the $\mathrm{pH}$ remained stable, after nine years of the treatments, at the sites that received mineral fertilization and only $\mathrm{K}$ supplementation, when compared to the soil $\mathrm{pH}$ before the treatments' application (Table 1). The lowest $\mathrm{pH}$ values were observed in the sites that received the residue and in the control treatment (Table 3). 
Table 3. Mean values of $\mathrm{pH}\left(\mathrm{CaCl}_{2}\right)$ in soil recovered with sewage sludge $\left(\mathrm{Mg} \mathrm{ha}^{-1}\right)$ and native species of the Atlantic Forest, up to $100 \mathrm{~cm}$ depth, nine years after the application of the treatments.

Tabela 3. Valores médios de $\mathrm{pH}\left(\mathrm{CaCl}_{2}\right)$ em solo recuperado com lodo de esgoto $\left(\mathrm{Mg} \mathrm{ha}^{-1}\right)$ e espécies nativas da Mata Atlântica, até $100 \mathrm{~cm}$ de profundidade, nove anos após a aplicação dos tratamentos.

\begin{tabular}{cllllll}
\hline & Treatments & \multicolumn{5}{c}{ Depth $(\mathrm{cm})$} \\
\cline { 2 - 6 } & & $0-20$ & $20-40$ & $40-60$ & $60-80$ & $80-100$ \\
\hline $\mathrm{pH}$ & 0 & $3.98 \mathrm{~b}$ & $4.18 \mathrm{bc}$ & $4.09 \mathrm{~cd}$ & $4.10 \mathrm{~b}$ & $4.13 \mathrm{ab}$ \\
$\mathrm{CaCl}_{2}$ & $\mathrm{NPK}$ & $4.34 \mathrm{a}$ & $4.40 \mathrm{a}$ & $4.46 \mathrm{a}$ & $4.23 \mathrm{ab}$ & $4.28 \mathrm{a}$ \\
& $\mathrm{K}$ & $4.34 \mathrm{a}$ & $4.37 \mathrm{ab}$ & $4.31 \mathrm{ab}$ & $4.34 \mathrm{a}$ & $4.29 \mathrm{a}$ \\
& 2.5 & $4.03 \mathrm{~b}$ & $4.06 \mathrm{c}$ & $4.25 \mathrm{bc}$ & $4.10 \mathrm{~b}$ & $4.20 \mathrm{ab}$ \\
& 5 & $3.97 \mathrm{~b}$ & $4.11 \mathrm{c}$ & $4.01 \mathrm{~d}$ & $4.06 \mathrm{~b}$ & $4.05 \mathrm{~b}$ \\
& 10 & $3.98 \mathrm{~b}$ & $4.01 \mathrm{c}$ & $4.12 \mathrm{bcd}$ & $3.97 \mathrm{bc}$ & $4.05 \mathrm{~b}$ \\
& 15 & $3.98 \mathrm{~b}$ & $4.05 \mathrm{c}$ & $4.02 \mathrm{~d}$ & $4.07 \mathrm{~b}$ & $4.02 \mathrm{~b}$ \\
& 20 & $3.98 \mathrm{~b}$ & $3.99 \mathrm{c}$ & $4.10 \mathrm{~cd}$ & $3.99 \mathrm{bc}$ & $4.04 \mathrm{~b}$ \\
\hline
\end{tabular}

The averages followed by equal letters in the column do not differ statistically from each other by the Tukey test at 5\% probability.

The levels of copper, iron, zinc and boron were significantly influenced by the application of the treatments in all the depths sampled. The manganese did not present significant values only in the layer of 20-40 cm depth.

Furthermore, the highest levels of copper and iron were obtained in the areas that received the highest dose of sewage sludge $\left(20 \mathrm{Mg} \mathrm{ha}^{-1}\right)$ in all soil depths sampled (Table 4). Manganese presented maximum levels in sites that only received potassium supplementation in the soil surface layer and, in the other depths, the highest values were observed in the areas that received sewage sludge (Table 4).

The levels of boron and zinc presented significant effects towards the application of treatments in all depths sampled. For each layer of soil sampled, it was possible to adjust regression equations of their levels (boron and zinc) in function of the applied sludge doses (Figures 2 and 3).

The maximum value of boron was $0.30 \mathrm{mg} \mathrm{dm}^{-3}$, obtained in the $20-40 \mathrm{~cm}$ depth layer with the application of $20 \mathrm{Mg} \mathrm{ha}^{-1}$ of residue, and the minimum was $0.16 \mathrm{mg} \mathrm{dm}^{-3}$ in the $80-100 \mathrm{~cm}$ layer in the control treatment (Figure 2).

Table 4. Mean values of copper $(\mathrm{Cu})$, iron $(\mathrm{Fe})$ and manganese $(\mathrm{Mn})\left(\mathrm{mg} \mathrm{dm}^{-3}\right)$ in soil recovered with sewage sludge $\left(\mathrm{Mg} \mathrm{ha}^{-1}\right)$ and native species of the Atlantic Forest, up to $100 \mathrm{~cm}$ depth, at nine years after the application of the treatments.

Tabela 4. Valores médios do cobre $(\mathrm{Cu})$, ferro $(\mathrm{Fe})$ e manganês $(\mathrm{Mn})\left(\mathrm{mg} \mathrm{dm}^{-3}\right)$ em solo recuperado com lodo de esgoto $\left(\mathrm{Mg} \mathrm{ha}^{-1}\right)$ e espécies nativas da Mata Atlântica, até $100 \mathrm{~cm}$ de profundidade, aos 9 anos após a aplicação dos tratamentos.

\begin{tabular}{lllllll}
\hline & Treatments & \multicolumn{5}{c}{ Depth $(\mathrm{cm})$} \\
\cline { 2 - 6 } & 0 & $0-20$ & $20-40$ & $40-60$ & $60-80$ & $80-100$ \\
\hline $\mathrm{Cu}$ & $0.48 \mathrm{c}$ & $0.35 \mathrm{c}$ & $0.43 \mathrm{c}$ & $0.35 \mathrm{~b}$ & $0.38 \mathrm{~b}$ \\
& $\mathrm{~K}$ & $0.68 \mathrm{c}$ & $0.53 \mathrm{bc}$ & $0.50 \mathrm{c}$ & $0.45 \mathrm{~b}$ & $0.40 \mathrm{~b}$ \\
& 2.5 & $0.43 \mathrm{c}$ & $0.38 \mathrm{c}$ & $0.45 \mathrm{c}$ & $0.40 \mathrm{~b}$ & $0.35 \mathrm{~b}$ \\
& 5 & $1.10 \mathrm{c}$ & $0.68 \mathrm{bc}$ & $0.64 \mathrm{bc}$ & $0.51 \mathrm{~b}$ & $0.40 \mathrm{~b}$ \\
& 10 & $2.05 \mathrm{bc}$ & $1.30 \mathrm{c}$ & $1.13 \mathrm{bc}$ & $0.95 \mathrm{~b}$ & $0.83 \mathrm{~b}$ \\
& 15 & $3.20 \mathrm{~b}$ & $1.58 \mathrm{bc}$ & $1.65 \mathrm{ab}$ & $1.23 \mathrm{~b}$ & $1.15 \mathrm{~b}$ \\
& 20 & $3.25 \mathrm{~b}$ & $1.80 \mathrm{~b}$ & $1.30 \mathrm{abc}$ & $1.23 \mathrm{~b}$ & $1.20 \mathrm{~b}$ \\
& 0 & $6.50 \mathrm{a}$ & $3.83 \mathrm{a}$ & $2.63 \mathrm{a}$ & $2.78 \mathrm{a}$ & $1.76 \mathrm{a}$ \\
\hline $\mathrm{Fe}$ & $\mathrm{NPK}$ & $53.75 \mathrm{c}$ & $45.25 \mathrm{c}$ & $42.75 \mathrm{c}$ & $37.50 \mathrm{~b}$ & $43.50 \mathrm{~b}$ \\
& $\mathrm{~K}$ & $67.00 \mathrm{~b}$ & $48.75 \mathrm{c}$ & $48.25 \mathrm{c}$ & $44.25 \mathrm{~b}$ & $52.25 \mathrm{~b}$ \\
& 2.5 & $50.25 \mathrm{c}$ & $46.50 \mathrm{c}$ & $46.50 \mathrm{c}$ & $40.00 \mathrm{~b}$ & $44.25 \mathrm{~b}$ \\
& 5 & $76.00 \mathrm{~b}$ & $56.00 \mathrm{c}$ & $57.75 \mathrm{bc}$ & $48.25 \mathrm{~b}$ & $36.50 \mathrm{~b}$ \\
& 10 & $112.25 \mathrm{ab}$ & $85.00 \mathrm{bc}$ & $73.75 \mathrm{abc}$ & $63.00 \mathrm{~b}$ & $58.75 \mathrm{ab}$ \\
& 15 & $127.00 \mathrm{a}$ & $99.00 \mathrm{ab}$ & $98.75 \mathrm{ab}$ & $82.75 \mathrm{ab}$ & $68.25 \mathrm{ab}$ \\
& 20 & $133.25 \mathrm{a}$ & $96.75 \mathrm{ab}$ & $83.25 \mathrm{abc}$ & $75.50 \mathrm{ab}$ & $72.50 \mathrm{ab}$ \\
$\mathrm{Mn}$ & 0 & $136.75 \mathrm{a}$ & $131.0 \mathrm{a}$ & $117.50 \mathrm{a}$ & $115.0 \mathrm{a}$ & $107.75 \mathrm{a}$ \\
\hline $\mathrm{NPK}$ & $1.65 \mathrm{ab}$ & $1.32 \mathrm{~ns}$ & $1.43 \mathrm{~b}$ & $1.40 \mathrm{~b}$ & $1.20 \mathrm{~b}$ \\
& $\mathrm{~K}$ & $1.67 \mathrm{ab}$ & $1.50 \mathrm{~ns}$ & $1.45 \mathrm{~b}$ & $1.43 \mathrm{~b}$ & $1.33 \mathrm{~b}$ \\
& 2.5 & $2.20 \mathrm{a}$ & $1.35 \mathrm{~ns}$ & $1.55 \mathrm{~b}$ & $1.50 \mathrm{~b}$ & $1.33 \mathrm{~b}$ \\
& 5 & 1.50 & $1.30 \mathrm{~ns}$ & $1.70 \mathrm{ab}$ & $1.55 \mathrm{~b}$ & $1.45 \mathrm{ab}$ \\
& 10 & $1.60 \mathrm{ab}$ & $1.47 \mathrm{~ns}$ & $1.65 \mathrm{ab}$ & $1.63 \mathrm{ab}$ & $1.63 \mathrm{ab}$ \\
& 15 & $1.50 \mathrm{ab}$ & $1.42 \mathrm{~ns}$ & $2.18 \mathrm{a}$ & $2.03 \mathrm{a}$ & $1.80 \mathrm{a}$ \\
& 20 & $2.05 \mathrm{ab}$ & $1.40 \mathrm{~ns}$ & $1.90 \mathrm{ab}$ & $1.80 \mathrm{ab}$ & $1.80 \mathrm{a}$ \\
& 15 & $1.42 \mathrm{~b}$ & $1.55 \mathrm{~ns}$ & $1.98 \mathrm{ab}$ & $2.00 \mathrm{a}$ & $1.88 \mathrm{a}$ \\
\hline
\end{tabular}

The averages followed by equal letters in the column do not differ statistically from each other by the Tukey test at $5 \%$ probability. 
In addition, zinc showed a maximum level of $1.78 \mathrm{mg} \mathrm{dm}^{-3}$ in the $60-80 \mathrm{~cm}$ depth layer with the application of $15 \mathrm{Mg} \mathrm{ha}^{-1}$ (Figure 3). Meanwhile, the lowest value $\left(0.02 \mathrm{mg} \mathrm{dm}^{-3}\right.$ ) was observed at the depth of $80-100 \mathrm{~cm}$ in the control treatment (Figure 3).

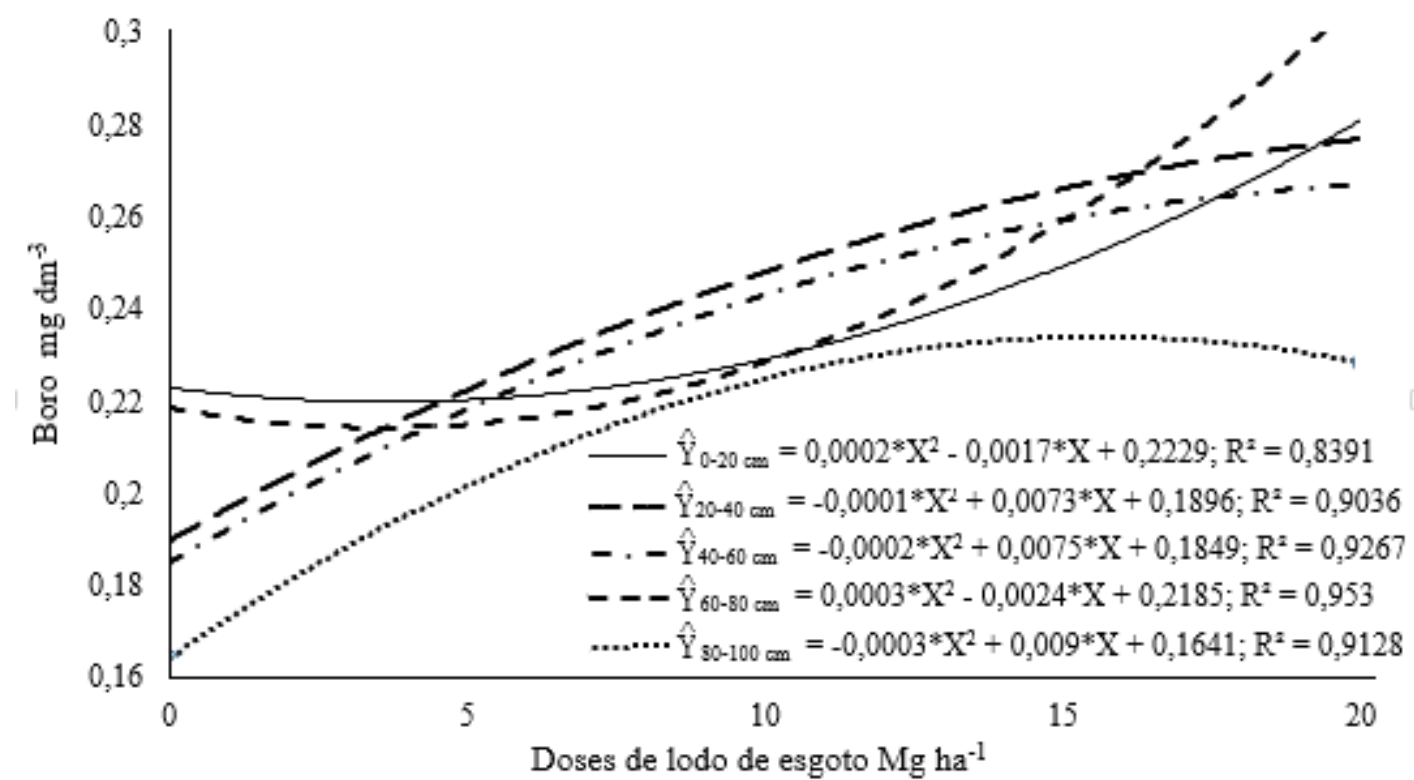

Figure 2. Boron levels $\left(\mathrm{mg} \mathrm{dm}^{-3}\right)$ as a function of the sewage sludge doses $\left(\mathrm{Mg} \mathrm{ha}^{-1}\right)$ applied in the 0-20, 20-40, 40-60, 60-80 and 80-100 $\mathrm{cm}$ depth, nine years after the application of the treatments. * Significant at $5 \%$ probability.

Figura 2. Níveis de boro $\left(\mathrm{mg} \mathrm{dm}^{-3}\right)$ em função das doses de lodo de esgoto $\left(\mathrm{Mg} \mathrm{ha}^{-1}\right)$ aplicadas, nas camadas de 0-20, 20-40, 40-60, 60-80 e 80-100 cm de profundidade, nove anos após a aplicação dos tratamentos. * Significativo a $5 \%$ de probabilidade.

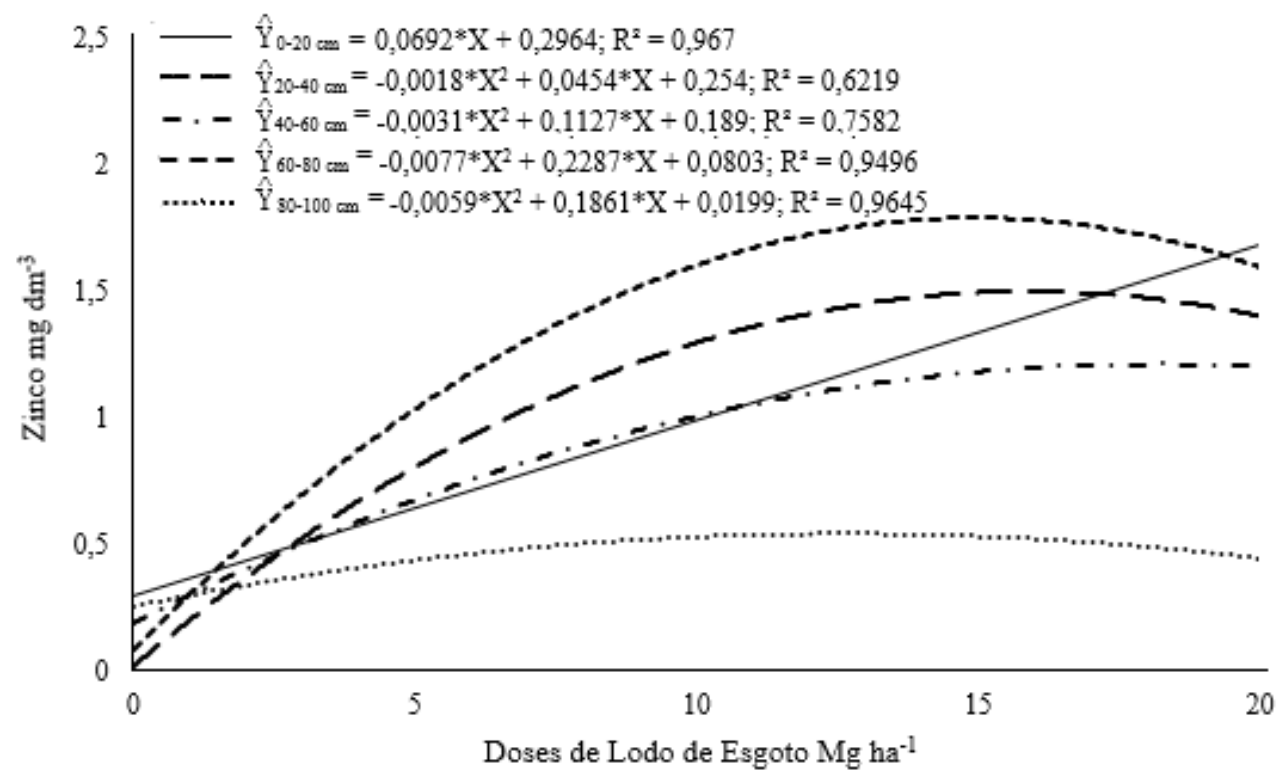

Figure 3. Zinc levels $\left(\mathrm{mg} \mathrm{dm}^{-3}\right)$ as a function of the sewage sludge doses $\left(\mathrm{Mg} \mathrm{ha}^{-1}\right)$ applied in the 0-20, 20-40, 40$60,60-80$ and 80-100 cm layers of depth, nine years after the application of the treatments. *Significant at $5 \%$ probability

Figura 3. Níveis de zinco $\left(\mathrm{mg} \mathrm{dm}^{-3}\right)$ em função das doses de lodo de esgoto $\left(\mathrm{Mg} \mathrm{ha}^{-1}\right)$ aplicadas, nas camadas de 0-20, 20-40, 40-60, 60-80 e 80-100 cm de profundidade, nove anos após a aplicação dos tratamentos. *Significativo a $5 \%$ de probabilidade.

\section{DISCUSSION}

The effect of sewage sludge application on soil $\mathrm{pH}$ is dependent on the type of treatment the residue received, rate and frequency of application of the sludge and soil properties, such as texture and buffering capacity

FLORESTA, Curitiba, PR, v. 49, n. 3, p. 485 - 492, jul/set 2019. 
(OLIVEIRA et al., 2002). In this study, the application of sewage sludge to degraded soil did not provide changes in $\mathrm{pH}$ in the soil surface layer when compared to the control treatment. If compared with the $\mathrm{pH}$ of the soil before the installation of the experiment, the current $\mathrm{pH}$ of the soil in the areas that received it and in the control treatment suffered a decrease, which can be explained by the acidifying effect of these residues. In turn, this effect was attributed to the nitrification reactions, the prospective oxidation of sulfites, and the production of organic acids produced during the microbiological decomposition of the organic matter present in the sewage sludge (DOWDY et al., 1991). Additionally, several studies have also reported soil acidification due to the application of sewage sludge, such as Bezerra et al. (2006), Kitamura et al. (2008), and Zuba Junio et al. (2015).

In the sites that received treatments with mineral fertilization and only supplementation with potassium, the $\mathrm{pH}$ of the soil was higher when compared to the treatments with doses of sewage sludge and with the control treatment, fact that can be explained by the accomplishment of the liming in these places before the application of treatments. If the $\mathrm{pH}$ of the above treatments is compared with that of before the application of treatments, it remained stable.

The availability of copper, along with other cationic micronutrients such as zinc, iron and manganese, is negatively affected in soils with pH values above 6.5 (CAMARGO et al., 2001). In the case of the present study, the $\mathrm{pH}$ of the soil favored the availability of the micronutrients mentioned above and their contents were increased by the addition of sewage sludge, which acted as source for the same. Copper and iron presented high levels for the state of São Paulo, according to Raij et al. (2001), in all layers of soil sampled.

In this way, similar results were observed by Vieira et al. (2005) in a study of a fertilized soil with sewage sludge in which was cultivated soybean. So, it showed an increase of the copper and zinc contents in the treatments with the residue. Moreover, Bezerra et al. (2006) also found an increase in copper, iron and zinc contents in a soil recovered with sewage sludge.

The iron presented higher levels in the sites that received high doses of sewage sludge in the surface layer, evidencing its low mobility in the profile, as well as copper. The mobility of heavy metals is determined by the soil characteristics, such as original metal content, texture, clay types and contents, $\mathrm{pH}$, cation exchange capacity, organic matter content, among others, influencing adsorption/desorption reactions, precipitation/dissolution, complexation and oxidation (OLIVEIRA; MATTIAZZO, 2001). In soils treated with sewage sludge, the mobility of heavy metals has been indicated as null or very low (MESSIAS et al., 2007). Messias et al. (2007) when evaluating the mobility of micronutrients in soil treated with sewage sludge, observed that iron, zinc and copper elements were retained in the soil layer that received the residue, evidencing its low mobility.

The manganese presented a greater mobility in the soil profile when compared to copper and iron, in the places that received the sewage sludge application, however, its higher content was verified in the 0-20 cm layer in the sites that received the application of potassium. In contrast, these results disagree with Lana et al. (2014), because when studying iron and manganese in the soil profile in response to organic and mineral fertilization, they verified higher manganese content in the soil surface layer that received organic fertilization. Yet, Nascimento et al. (2004) found an increase in the levels of copper, iron, zinc and manganese in the surface layer of a soil treated with sewage sludge and cultivated with maize and beans, differing from this present study in relation to the manganese element. In general, in all the treatments analyzed here, the levels of manganese in the soil were considered medium, according to Raij et al. (2001).

Furthermore, boron presented low and medium contents in all the treatments analyzed, according to Raij et al. (2001). The highest value was obtained in the layer of $20-40 \mathrm{~cm}$ depth with application of the maximum dose of sewage sludge, which indicates that this element was little leached. Part of the boron that is added to the soil remains soluble and can be leached into the soil profile (ROSOLÉM; BÍSCARO, 2007). Also, boron that is not, initially, in solution can be desorbed and leached (COMMUNAR; KEREN, 2007). Despite the low pH of the soil and its sandy texture, which negatively affects its availability and propitiates its leaching, the boron may have been retained in the organic matter of the soil, which was increased by the addition of sewage sludge.

Lobo et al. (2012), when studying the effect of sewage sludge application on soil fertility under sunflower cultivation, found that the micronutrients copper, iron, zinc and boron increased their levels at the sites that received residue. However, soil boron levels still remained low even with addition via sewage sludge, indicating that the residue is a poor source of this micronutrient, in agreement with the results of the present study. Nevertheless, contrasting results were found by Araújo et al. (2009), who observed that the application of sewage sludge did not alter soil boron levels, increasing only iron and zinc contents.

Zinc presented its greatest content in the depth of $60-80 \mathrm{~cm}$, demonstrating that this element underwent leaching with the passage of time. This downward vertical movement in the soil profile, depending on the dose, can become toxic and cause contamination to the environment (NASCIMENTO et al., 2010), expressing its pollutant potential directly on soil organisms, by the availability to the plants and surface and subsurface water contamination (OLIVEIRA et al., 2002). Nonetheless, the levels of zinc found in this study varied from low to high (RAIJ et al.,2001), but outside the toxicity range. In a study on soil micronutrient profile mobility in response to the application of sewage sludge, Messias et al. (2007) did not observe zinc leaching. These results differed from this study probably due to the short evaluation time after the application of residue (60 days), along with it not being in the field condition. 
In synthesis, the zinc contents increased with the application of sewage sludge, and its greatest increase in soil occurred at the sites that received the maximum dose of the residue. Similar results were observed by Chiba et al. (2008) in a study of an Argisol treated with sewage sludge and cultivated with soybean, which showed an increase of the copper and zinc contents in the treatments with residue. Araújo and Nascimento (2005) also verified increases in total zinc contents in two types of soils (Latosol and Argisol) incubated with sewage sludge and cultivated with maize.

\section{CONCLUSIONS}

The analyzes carried out after nine years of the application of treatments allow us to conclude that:

- The micronutrient contents analyzed increase with the application of sewage sludge in all depths sampled, except for manganese in depth of 20-40 cm.

- The application of sewage sludge decreases soil $\mathrm{pH}$ in all depths sampled.

- Only manganese and zinc present mobility in the soil profile due to the application of the residue.

\section{ACKNOWLEDGMENTS}

To the Sao Paulo Research Foundation (FAPESP) and CAPES (Improvement Coordination of Personnel Higher Education) for the project funding and grant of the doctoral scholarship (Process $\mathrm{N}^{\circ} 2013$ / 22350-3). Also to the company Suzano Paper and Cellulose S/A for the concession of the experimental area and technical support in the project.

\section{REFERENCES}

ANDREOLI, CV \& PEGORINI, ES Public management of the agricultural use of sewage sludge. In: BETTIOL, W.; CAMARGO, OA (Eds.). Environmental impact of the agricultural use of sewage sludge. Jaguariúna CNPMA, 2000. p. 281-312.

ARAÚJO, JCT \& NASCIMENTO, CWA Fractionation and availability of zinc by different extractors in soils incubated with sewage sludge. Brazilian Journal of Soil Science, v. 29, p. 977-985, 2005.

ARAÚJO, FF; GIL, FC; TIRITAN, CS Sewage sludge on soil fertility, nutrition of Brachiaria decumbens and dehydrogenase activity. Pesquisa Agropecuária Tropical, v. 39, n. 1, p. 1-6, 2009.

BEZERRA, F.B.; OLIVEIRA, MACL; PEREZ, DV; ANDRADE, AG \& MENEGUELLI, NA Sewage sludge in revegetation of degraded area. Pesquisa Agropecuária Brasileira, v. 41, n. 1, p. 469-476, 2006.

CAMARGO, OA; ALLEONI, LRF; CASAGRANDE, JC Micronutrient reactions and toxic elements in soil. In: FERREIRA, ME; CRUZ, MCP; RAIJ, B. van \& ABREU, CA Eds. Micronutrients and toxic elements in agriculture. Jaboticabal, CNPq / FAPESP / POTAFOS, 2001. p. 89-124.

CHIBA, MK; MATTIAZZO, ME; OLIVEIRA, FC Sugarcane cultivation in Argissolo treated with sewage sludge. Brazilian Journal of Soil Science, v. 32, p. 653-662, 2008.

COMMUNAR, G. \& KEREN, R. Effect of transient irrigation on boron transport in soils. Soil Science Society of America Journal, v. 71, p. 306-313, 2007.

DOWDY, RH; LATTERELL, JJ; HINESLY, TD; GROSSMAN, RB \& SULLIVAN, DL Trace metal movement in an Aeric Ochraqualf following 14 years of annual sludge applications. Journal of Environmental Quality, v. 20, p. 119-123, 1991.

EMPRESA BRASILEIRA DE PESQUISA AGROPECUÁRIA - EMBRAPA. EMBRAPA - National Center for Soil Research. Brazilian soil classification system. 3rd Edition. Brasília, Embrapa-SPI / Rio de Janeiro, Embrapa Solos, 2013. 342p.

GONÇALVES, JLM; RAIJ, B. van; GONÇALVES, JC Florestais. In: RAIJ, B. van et al. (Eds.) Fertilization and liming recommendations for the State of São Paulo. Campinas: Instituto Agronômico e Fundação, 1996. p. 247259.

KITAMURA, AE; ALVES, MC; SUZUKI, LGAS; GONZALEZ, AP Recovery of degraded soil with the application of green manures and sewage sludge. Brazilian Journal of Soil Science, v. 32, p. 405-416, 2008.

LANA, RMQ; REZENDE, RV; LANA, AMQ; SILVA, AA; VITORINO, LB; GOMIDES, JN Iron and manganese in soil profile in Saccharum officinalis fertilized with organic waste. Bioscience Journal, v. 30, n. 1, p. 131-139, 2014

LOBO, TF; LAMBERT, RA; GRASSI FILHO, H. Doses of sewage sludge on soil fertility after sunflower harvest. Scientia Agraria, v. 13, n. 1, p. 29-37, 2012. 
MESSIA, AS; SILVA, HA; LIMA, VN; SOUZA, JEG Evaluation of the mobility of micronutrients in treated soil with sewage sludge. Brazilian Journal of Regional Management and Development, v. 3, n. 3, p. 193-211, 2007.

BIRTH, CWA; BARROS, DAS; MELO, EEC; OLIVEIRA, AB Chemical alterations in soils and corn and bean growth after application of sewage sludge. Brazilian Journal of Soil Science, v. 28, p. 385-392, 2004.

BIRTH, PC; LANI, JL; MENDONÇA, ES; ZOFFOLI, HJO; PEIXOTO, HTM Organic matter contents and characteristics of the hydromorphic soils of Espírito Santo. Revista Brasileira Ciência do Solo, v. 34, p. 339-348, 2010.

OLIVEIRA, FC; MATTIAZZO, ME; MARCIANO, CR; ROSSETO, R. Effects of successive applications of sewage sludge on a dystrophic Yellow Latosol cultivated with sugarcane: organic carbon, electrical conductivity, pH and CTC. Revista Brasileira de Ciência do Solo, v. 26, p. 505-519, 2002.

OLIVEIRA, F. C. \& MATTIAZZO, M. E. Metais pesados em Latossolo tratado com lodo de esgoto e plantas de cana-de-açúcar. Scientia Agricola, v. 58, p. 581-593, 2001.

RAIJ, B. van; From ANDRADE, JC; CANTARELLA, H.; QUAGGIO, JA, eds. Análise química para avaliação da fertilidade de solos tropicais. Campinas, Instituto Agronômico, 2001. 284p.

RICCI, AB; PADOVANI, VCR; PAULA JÚNIOR, DR Use of stabilized sewage sludge in a decapitated soil. Revista Brasileira de Ciência do Solo, v. 34, p. 535-542, 2010.

ROSOLEM, CA \& BÍSCARO, T. Adsorption and boron leaching in Red-Yellow Latosol. Pesquisa Agropecuária Brasileira, v. 42, n. 10, p. 1473-1478, 2007.

SILVA, LCR; BAPTISTA, GMM; SANTOS, PF Chemical fertility of a substrate treated with sewage sludge and composed of household waste. Revista Brasileira de Engenharia Agrícola e Ambiental, v. 14, p. 538-544, 2010.

SHEPPARD, M. J. \& THIBAULT, D. H. Desorption and Extraction of Selected Heavy Metals from Soils. Soil Science Society of America Journal, v. 56, p. 415-423, 1992.

VIEIRA, RF; TANAKA, RT; TSAI, MS, PEREZ, DV; SOUSA SILVA, CMM Availability of nutrients in soil, grain quality and soybean yield in soil fertilized with sewage sludge. Revista Brasileira de Ciência do Solo, v. 40, p. 919-926, 2005.

ZUBA JUNIO, GR; SAMPAIO, RA; NASCIMENTO, AL; FERNANDES, LA; LIMA, NN; CARNEIRO, JP Attributes of the soil fertilized with sewage sludge and calcium and magnesium silicate. Revista Brasileira de Engenharia Agrícola e Ambiental, v. 14, p. 538-544, 2010. 